\title{
MUC2 gene promoter methylation in mucinous and non-mucinous colorectal cancer tissues
}

\author{
KEISUKE OKUDAIRA ${ }^{1,2}$, SANJAY KAKAR ${ }^{3}$, LISA CUN $^{1}$, ESTER CHOI $^{1}$, RINA WU DECAMILLIS ${ }^{4}$, \\ SOICHIRO MIURA ${ }^{2}$, MARVIN H. SLEISENGER ${ }^{1}$, YOUNG S. KIM ${ }^{1}$ and GOUREN DENG ${ }^{1}$ \\ ${ }^{1}$ Department of Medicine, Gastrointestinal Research Laboratory, Veterans Affairs Medical Center, \\ University of California San Francisco, San Francisco, CA, USA; ${ }^{2}$ Department of Internal Medicine, \\ National Defense Medical College, Saitama, Japan; ${ }^{3}$ Department of Pathology, Veterans Affairs Medical Center, \\ University of California San Francisco, San Francisco; ${ }^{4}$ Genemed Biotechnologies, Inc., South San Francisco, CA, USA
}

Received October 13, 2009; Accepted November 30, 2009

DOI: 10.3892/ijo_00000552

\begin{abstract}
Abundant mucin production and MUC2 expression is the key feature of mucinous colorectal cancer (CRC). Although MUC2 gene methylation has been thought to play an important role in loss of MUC2 expression, the tissues are difficult to analyze because of the cellular heterogeneity of tissue samples. In the present study, we determined the role of region-specific methylation in the MUC2 promoter in MUC2 expression in CRC. Additionally, we optimized the conditions for quantification of methylation analysis in mucinous and non-mucinous CRC tissues. We identified two regions in MUC2 promoter, region A (-289 and -274) and region C (-193 and -160), that correlated with loss of MUC2 expression by comparing the methylation status in $13 \mathrm{CRC}$ cell lines with no or low MUC2 expression and those in 4 cell lines with high MUC2 expression. To prove the correlation of MUC2 methylation status and loss of expression in CRC tissues, MUC2 methylation status in tumors needs to be determined. Since the critical $\mathrm{CpG}$ sites have been identified in cell lines by sequencing, a more rapid and sensitive methylation specific PCR (MSP) was used. We conducted MSP at 3 CpG sites $(-289,-274,-193)$ in 19 mucinous and 34 non-mucinous CRC tissues because this analysis worked at only these sites in the preliminary cell line experiments. Our results showed that methylation status of mucinous CRC was significantly lower than that of non-mucinous CRC at 3 sites $(-289 ; \mathrm{p}=0.001,-274 ; \mathrm{p}=0.013,-193 ; \mathrm{p}=0.001)$, and correlated with high level of MUC2 expression as determined by immunohistochemistry. Besides, these results indicated that MUC2 expression and mucin contents decreased in
\end{abstract}

Correspondence to: Dr Young S. Kim, GI Section (111B), Veterans Affairs Medical Center, 4150 Clement St. San Francisco, CA 94121, USA

E-mail: young.kim@ucsf.edu

Key words: mucinous colorectal cancer, MUC2, DNA methylation accordance with the increase of methylation status. We concluded that low methylation status of MUC2 gene plays a predominant role in high level MUC2 expression in mucinous CRC.

\section{Introduction}

Mucinous colorectal cancer (CRC), which is a subtype of $\mathrm{CRC}$, is characterized by abundant amount of extracellular mucin consisting predominantly of MUC2 protein. Mucinous CRC represents $5-15 \%$ of all CRCs $(1,2)$ and clinicopathological studies indicate that mucinous CRC often presents at an advanced stage and is likely to invade the adjacent organs (3). There is also more extensive lymph node involvement beyond the pericolonic region and more frequent peritoneal dissemination and recurrence (4), and therefore, less readily resectible and often carry a worse prognosis $(3,4)$.

In addition, mucinous cancer has recently been reported to have distinct genetic and epigenetic alterations compared to non-mucinous CRC. These include MSI, CIMP, BRAF, APC, KRAS and p53 mutation. MSI $(5,6)$, CIMP $(5,7)$ and $\operatorname{BRAF}(5,8,9)$ mutation is more frequently in mucinous CRC than in non-mucinous CRC. On the contrary, mutation of APC, KRAS and p53 occurred less in mucinous CRC than in non-mucinous CRC $(3,5,10)$. Therefore, these data indicated that mucinous CRC may have different pathways of pathogenesis from non-mucinous CRC.

MUC2 is one of the gel-forming secretory mucins that is expressed in goblet cells of small intestine and colon. Altered levels and patterns of expression of MUC2 have been reported in neoplasms. Since both secretory and membrane mucins have been shown to play an important role in cell-cell and cell-substratum interaction and signaling pathways, altered mucins may contribute to the altered biological properties of mucins in cancer cells. MUC2 gene has been reported to be regulated by many factors, such as, lipopolysaccharide (11), inflammatory cytokines (TNF- $\alpha$, interleukin-1, -4, -6, -9, -13) (12-17), growth factors (epidermal growth factor, transforming growth factors $\alpha$ and $\beta)$ (18-21), phorbol 12-myristate 13 -acetate (22), retinoic acid (23), surface molecules of non- 
typeable Haemophilus influenzae (11), and transcription factors (11,24-27), such as HATH1 and Cdx2. Promoter methylation of MUC2 has shown to play an important role in its expression. Expression of MUC2 gene products is correlated with methylation status in the proximal region of the promoter $(28,29)$, and suppression of the MUC2 gene in CRC cells in vitro and in vivo has been shown to be associated with methylation of the MUC2 promoter region (30-32). Methylation of cytosine residues at CpG dinucleotides is an important epigenetic change that has been linked to transcriptional repression and regulation of chromatin structure (30-32). Hamada et al examined methylation status of the MUC2 promoter region from position -1989 to position +288 upstream, a region that contains $59 \mathrm{CpG}$ sites, using bisulfite genomic sequencing in two pancreatic cell lines, and suggested that methylation of certain $\mathrm{CpG}$ sites may be critical for MUC2 regulation (33). Yamada et al analyzed histone modification at MUC2 promoter lesion in detail reporting that histone $\mathrm{H} 3$ modification in the $5^{\prime}$ flanking region play an important role in MUC2 gene expression (34).

Most of the experiments for analyzing the correlation of MUC2 gene methylation and its expression was shown by cell line studies as above $(11-13,15,17,19,21-25,28-31,33,34)$ and there is a need to extend studies in tissues. Tissue study is more complicated because cancer tissues contain several epithelial cell types and stromal cells.

First, we examined the effect of region-specific methylation in the MUC2 promoter on MUC2 expression in a cell line study. Using sodium bisulfite sequencing method, we tried to identify the responsible $\mathrm{CpG}$ sites correlated with MUC2 expression. Besides, we optimized the conditions for quantification of methylation analysis and conducted the MSP analysis at these sites in 19 mucinous and 34 nonmucinous CRC tissues because this sequencing method is not efficient for tissue study due to the contamination of other type of cells. We also examined the correlation of methylation status with MUC2 expression as determined by immunohistochemistry.

\section{Materials and methods}

Cell lines and 5-aza-dC treatment. Colorectal carcinoma cell lines SW1116, HT29, Lovo, HCT 8, Colo201, Colo320, CaCo2, SW620, LS174T, SW48, and H498 were obtained from American Type Culture Collection (Manassas, VA). Cell lines VACO5 and VACO10P were kindly provided by Dr Sanford D. Markowitz. RW2982 and RW7213 were from Dr Lance M. Tibbetts. RKO and C cells were from Dr Michael Brattain. Cells were grown in DMEM supplemented with $10 \%$ fetal bovine serum at $37^{\circ} \mathrm{C}$ with $5 \% \mathrm{CO}_{2}$ atmosphere.

Cells were seeded at $2 \times 10^{5}$ cells/T75 flask on day 0 . The cells were treated with $1 \mu \mathrm{M} 5$-aza-dC on day 0 and 2 . The medium was changed $24 \mathrm{~h}$ after the treatment. Cells were harvested on day 5 for analysis of MUC2 expression and methylation status of promoter.

Microdissection and DNA extraction. Tumors were microdissected from formalin-fixed, paraffin-embedded $7 \mu \mathrm{m}$ thick histological sections stained with haematoxylin and eosin using a surgical scalpel under microscopic guidance. For genomic DNA isolation, microdissected samples were incubated overnight at $56^{\circ} \mathrm{C}$ with $0.5 \%$ Tween-20 (Sigma, St. Louis, MO), $100 \mathrm{mM}$ of Tris-HCl buffer (pH 7.6), $1 \mathrm{mM}$ of EDTA and $20 \mu \mathrm{g}$ of proteinase $\mathrm{K}$ (Sigma). Proteinase $\mathrm{K}$ was then inactivated by incubating at $95^{\circ} \mathrm{C}$ for $10 \mathrm{~min}$, and the extracted DNA was stored at $-20^{\circ} \mathrm{C}$ until use.

Methylation analysis of MUC2 gene by sodium bisulfite sequencing and methylation-specific PCR (MSP)

Sequencing method. The extracted DNA was treated with sodium bisulfite using EZ DNA Methylation Kits ${ }^{\mathrm{TM}}$ (Zymo Reseach, Orange, CA) as recommended by the manufacturer. The treated DNA was amplified separately by PCR using two primer sets (F1/R1 and F2/R2) that are designed to amplify two overlapping fragments covering the entire promoter sequences of MAC2. The sequences of the primers are: F1, 5'GAGTTTGATTAGATTTGTTTTTGGTAGGAT, R1, 5'ACAAAAATCTAАTCCTTATATATCCTAACAAA; F2, 5'TGTTAGGATATATAAGGATTAGATTTTTGT, R2, 5'CAACCCGAACCAAAAACCTCAACAA. The PCR products were purified by electrophoresis on a $1.5 \%$ agarose gel and eluted with QIAquick gel extraction kit (Qiagen). One-third of the eluted DNA was mixed with 5 pmol of the corresponding primer and sequenced on an $\mathrm{ABI}$ sequencer with dye terminators (Applied Biosystem).

MSP method. The methylation status of MUC2 gene in mucinous CRC and non-mucinous CRC was determined by MSP analysis. The extracted DNA was treated with sodium bisulfite using EZ DNA Methylation Kits. Bisulfite-treated DNA was pre-amplified by 30 cycles of PCR with the primer set: F, 5'TTYGGGTGTGTGTTGGTATTTAGGT, R, 5'AACATCTACCAAATAATCAAAAAAACAACTA. Amplified DNA $(1 \mu \mathrm{l})$ was amplified separately by MSP with primer sets specific for methylated and unmethylated alleles. MSP was performed by 15 cycles with annealing temperature at $64^{\circ} \mathrm{C}$ for both studies. The primers sequences for each $\mathrm{CpG}$ sites and size of products are summarized in Table I.

Determination of MUC2 mRNA. Total RNA $(1 \mu \mathrm{g})$ isolated from cell lines was reverse-transcribed using random hexanucleotides (Boehringer-Mannheim) and SuperScript II reverse transcriptase (Life Technologies, Inc) in a volume of $50 \mu 1$. cDNA $(1 \mu \mathrm{l})$ was amplified by PCR, together with two primer sets. The first set was used for the MUC2 gene: F, 5'CTCAACGACAACCCCTACTA; R, 5'ATGGGAACA TCACGATACATG. The second primer set was for amplifying a $B$-actin fragment as an internal control: F, 5'TCAC CAACTGGGACGACATG; R, 5'ACCGGAGTCCATCACG ATG. The RT-PCR products were analyzed by electrophoresis on a $2 \%$ agarose gel, followed by ethidium bromide staining. The amount of each fragment was determined with a densitometer. The RNA expression level was represented as the ratio of the amount of MUC2 fragment over $\beta$-actin.

Mucin and MUC2 protein expression by histochemistry and immunohistochemistry

Histochemistry. We conducted H\&E staining to evaluate mucin contents in mucinous CRC and non-mucinous CRC tissues. This evaluation was also done by two of the authors. Mucin 
Table I. Primer sequences used in MUC2 methylation analysis.

\begin{tabular}{|c|c|c|c|}
\hline $\begin{array}{l}\text { CpG site in MUC2 } \\
\text { promoter region }\end{array}$ & $\begin{array}{l}\text { Forward } \\
\text { primer }\end{array}$ & $\begin{array}{l}\text { Reverse } \\
\text { primer }\end{array}$ & $\begin{array}{l}\text { Length } \\
\text { (bp) }\end{array}$ \\
\hline \multicolumn{4}{|l|}{-289} \\
\hline Methylated & AGATTTGTTTTTGGTAGGATATTTTTTTTTC & СААСССТАТААССТАААТАССААС & 106 \\
\hline Unmethylated & AGATTTGTTTTTGGTAGGATATTTTTTTTTT & САAСССТАТААССТАААТАССААС & 106 \\
\hline \multicolumn{4}{|l|}{-274} \\
\hline Methylated & GTTTATGGYGGGTTAAGGAGTTTGAT & ACCCGAAAAACACATACAACTACTAAAAAAACG & 105 \\
\hline Unmethylated & GTTTATGGYGGGTTAAGGAGTTTGAT & ACCCAAAAAACACATACAАCTACTAAAAAAACA & 105 \\
\hline \multicolumn{4}{|l|}{-193} \\
\hline Methylated & ATAGGGTTGTTTTATTTTGAAGAAGGTTGC & AACATCTACCAAATAATCAAAAAAACAACTA & 137 \\
\hline Unmethylated & ATAGGGTTGTTTTATTTTGAAGAAGGTTGT & AАCATCTACCAAATAATCAAAAAAACAACTA & 137 \\
\hline
\end{tabular}

contents of all samples are indicated as percentage in Table IV (mucinous CRC group) and V (non-mucinous CRC group). We considered CRC as mucinous cancer if its mucin content was over $50 \%$.

Immunohistochemistry. To determine the expression of MUC2 in CRC tissues, paraffin sections were stained with anti-MUC2 antibody, CCP58 (1:200; Zymed Laboratories, South San Francisco, CA). This murine CCP58 antibody was generated against a synthetic peptide of the MUC2 tandem repeat peptide region. After deparaffinisation, sections were subjected to heat-induced antigen retrieval in $10 \mathrm{mM}$ sodium citrate buffer in a pressure cooker (Biocare Medical, Walnut Creek, CA), pH 6.0 for $20 \mathrm{~min}$. Non-specific protein binding was blocked by incubating sections with serum blocking solution (Zymed) for $10 \mathrm{~min}$ at room temperature. Anti-MUC2 antibody was applied and incubated for $60 \mathrm{~min}$. Sections were rinsed in PBS followed by incubation of biotinylated secondary antibody (Zymed) for $10 \mathrm{~min}$. After a brief rinse, streptavidin-enzyme conjugate (Zymed) was applied and incubated for $10 \mathrm{~min}$. Sections were rinsed, followed by incubation with Liquid DAB Substrate Kit (Zymed). After counterstaining with haematoxylin, sections were dehydrated in graded ethanol and cleared in xylene before mounting. Positive staining is seen predominantly in the perinuclear cytoplasm of goblet cells.

Immunoreactivity was graded as - (negative),+ (positive) or ++ (strong positive). Semiquantitative staining of specimens was performed by evaluating the intensity of staining $(-, 0 ;+, 1 ;++, 2)$ and the percentage of tissue with positive staining $(0-100 \%)$. The percentage of tissue with positive staining was evaluated by examining and individually grading each low-power field (x10 objective lens) in every specimen. An integrated staining intensity score (IS) for the entire specimen was calculated by the formula: IS $=\sum(1 \times \mathrm{F}+)$ $+(2 \times \mathrm{F}++)$, where $\mathrm{F}=$ percent $(\%) \times 10$ field, as described previously $(35,36)$. The range was $0-2$, and a specimen was categorized as positive if the staining intensity score was greater than 0.10 . Normal colonic tissue was used as positive control. This evaluation was done individually by S. Kakar and K. Okudiara.
Statisitical analysis. Comparison of categorical variables including gender, tumor location, Dukes stage, methylation status of MUC2 gene promoter region were made using $\chi^{2}$ test or Fisher's exact test as appropriate. Methylation status of mucinous CRC and non-mucinous CRC was compared by Student's t-test. Mann-Whitney's U test was used for the comparison of MUC2 staining area (\%), the integrated staining intensity score (IS) and mucin contents (\%). Comparison of MUC2 staining area (\%), intensity score (IS) and mucin contents (\%) among no methylation group, low methylation group and high methylation group were examined by Student's t-test or Welch's t-test as appropriate.

\section{Results}

Analysis of methylation status in the CpG islands of MUC2 promoter by sequencing method in cell lines. We conducted the sodium bisulfite sequencing method to investigate the methylation status of MUC2 gene promoter in mucinous $\mathrm{CRC}$ and non-mucinous CRC cell lines (Figs. 1A and B, and 2). We analyzed 13 MUC2-non-expressing cell lines and four MUC2-expressing cell lines. As shown in these figures, there was an obvious difference between two groups especially in regions A and C. In these sites, all of MUC2non-expressing cell lines were highly methylated, and on the contrary, all MUC2-expressing ones were not methylated.

Relationship between methylation status of $C p G$ sites in MUC2 protein and MUC2 mRNA expression in cell lines. To examine the relationship between MUC2 methylation status and its expression level, we added 5-aza-dC which has the ability to decrease gene methylation level. We examined two highly-methylated cell lines, Lovo and HT29. As shown in Fig. 3A, methylation status in regions $\mathrm{A}$ and $\mathrm{C}$ was decreased in these cell lines followed by the reproduction of MUC2 (Fig. 3B). This cell line study indicated that methylation of MUC2 gene promoter region regulates its expression.

Methylation analysis of MUC2 gene promoter in cell lines. Since sequencing method does not work well in tissue samples, 
A

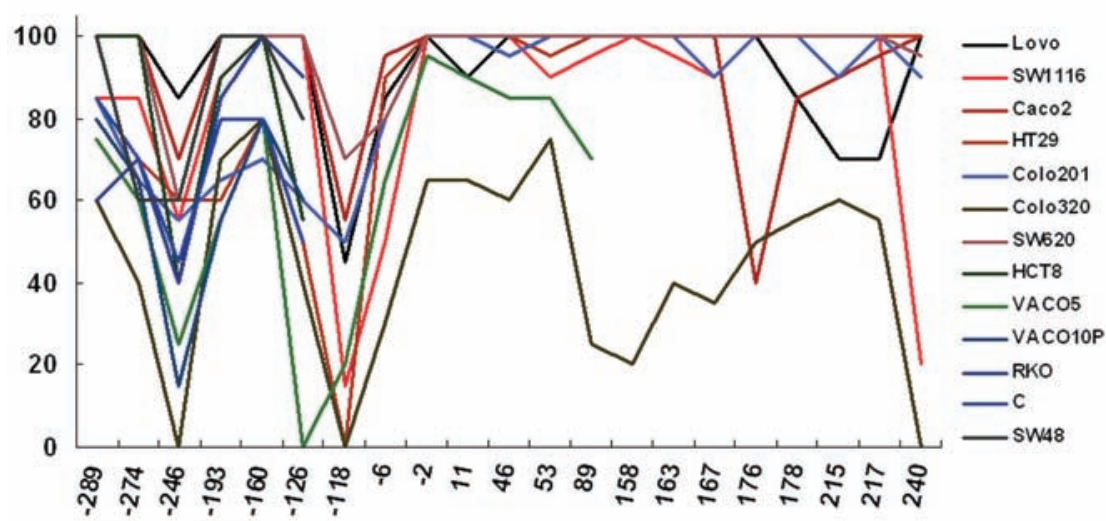

$\bar{A} \quad \bar{C}$

B

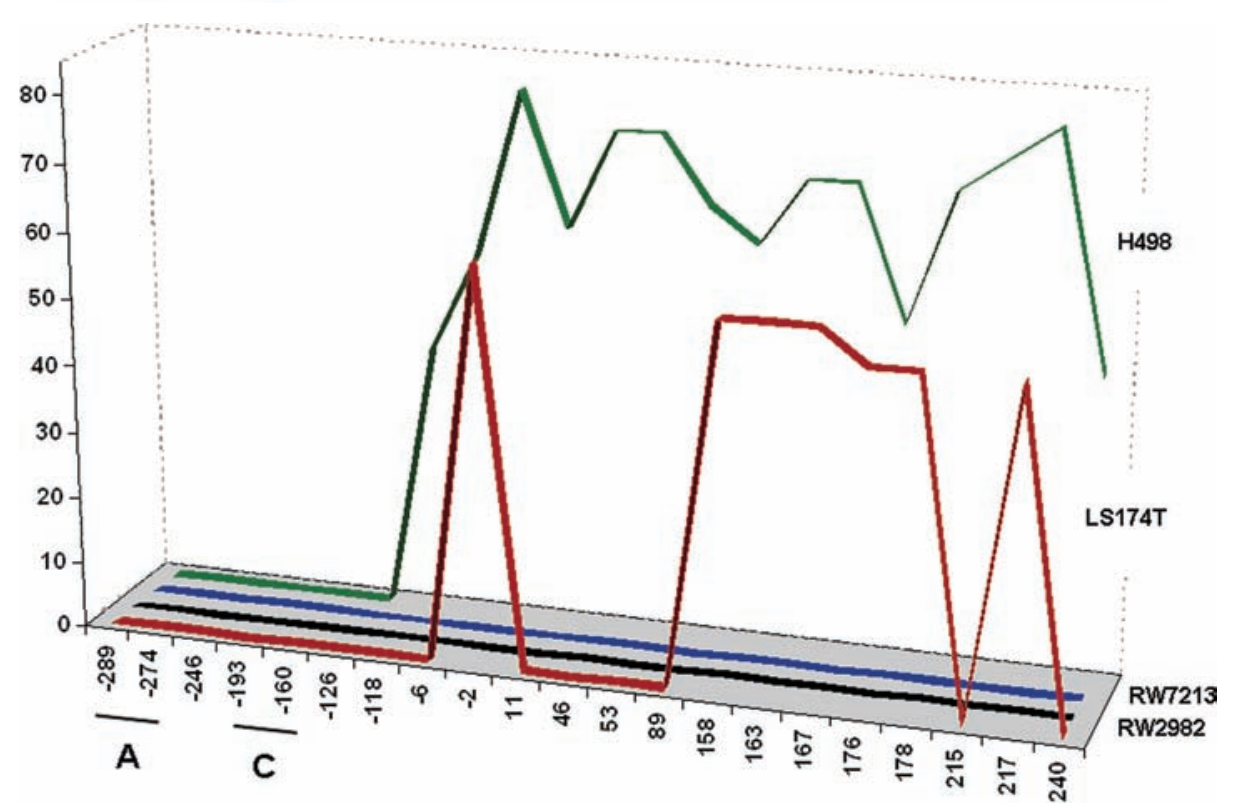

Figure 1. $\mathrm{NaHSO}_{3}$ sequencing analysis of methylation status of MUC2 gene. Methylation status of $21 \mathrm{CpG}$ sites $(-289$ to +240$)$ was examined. We considered -289 and -274 as region A, and -193 and -160 as region C. (A) Sequencing data of 13 MUC2-non-expressing CRC cell lines. Methylation statuses of region A and $\mathrm{C}$ are high in all cell lines. (B) Sequencing data of MUC2-expressing CRC cell lines. In 4 cell lines, methylation statuses of both areas are $0 \%$.

\begin{tabular}{ccccccc}
\multicolumn{5}{c}{ Methylation in MUC2 gene promoter } \\
\hline
\end{tabular}

Figure 2. Summary of methylation status of MUC2 gene in MUC2-non-expressing and MUC2-expressing cell lines. The methylation statuses of both CRC groups were very similar at regions A and $\mathrm{C}$. 
A

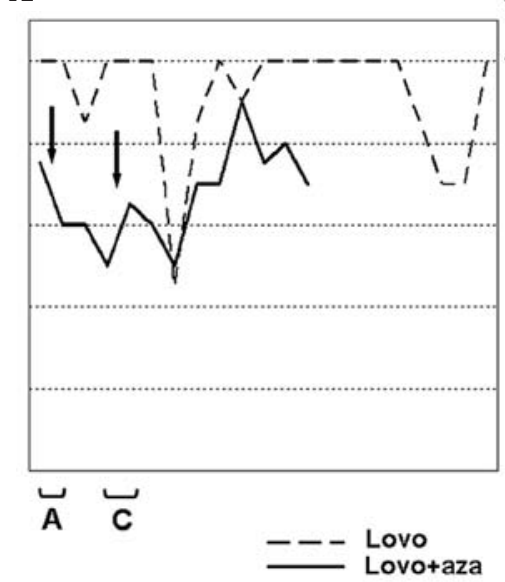

Methylation (\%)

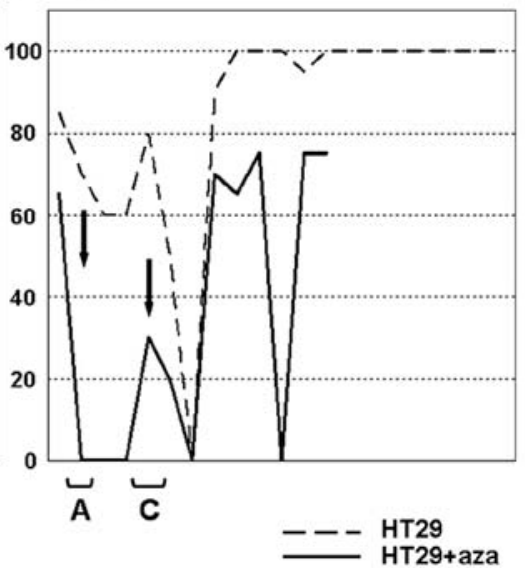

B

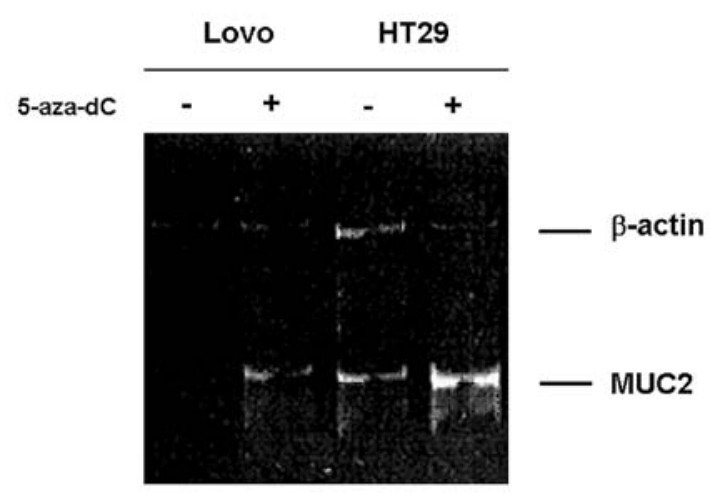

Figure 3. The effect on MUC2 methylation status of cell lines by 5-aza treatment. (A) Lovo and HT29 are highly-methylated cell lines. 5-aza-dC treatment decreased the MUC2 methylation level. Dotted lines are the methylation levels of Lovo and HT29. Solid lines are the treated cells. (B) MUC2 expression after the treatment. Demethylated cell lines expressed MUC2.

Table II. Clinico-pathological features of mucinous and non-mucinous colorectal cancers (CRC).

\begin{tabular}{lcc}
\hline Features & Mucinous CRC $(\mathrm{n}=19)$ & Non-mucinous CRC $(\mathrm{n}=34)$ \\
\hline Age (year) & $70.8 \pm 12.6$ & $69.6 \pm 14.0$ \\
Range & $47-90$ & $44-89$ \\
Gender & $10(52.7 \%)$ & \\
Male & $7(36.8 \%)$ & $19(55.9 \%)$ \\
Female & $2(10.5 \%)$ & $14(41.2 \%)$ \\
Unknown & & $1(2.9 \%)$ \\
Location of tumor & $7(36.8 \%)$ & \\
Right colon & $12(63.2 \%)$ & $14(41.2 \%)$ \\
Left colon & & $20(58.8 \%)$ \\
Dukes stage & $7(36.8 \%)$ & $22(64.7 \%)$ \\
A-B & $11(57.9 \%)$ & $11(32.4 \%)$ \\
C-D & $1(5.3 \%)$ & $1(2.9 \%)$ \\
Unknown & & N.S. \\
\hline
\end{tabular}

Region A
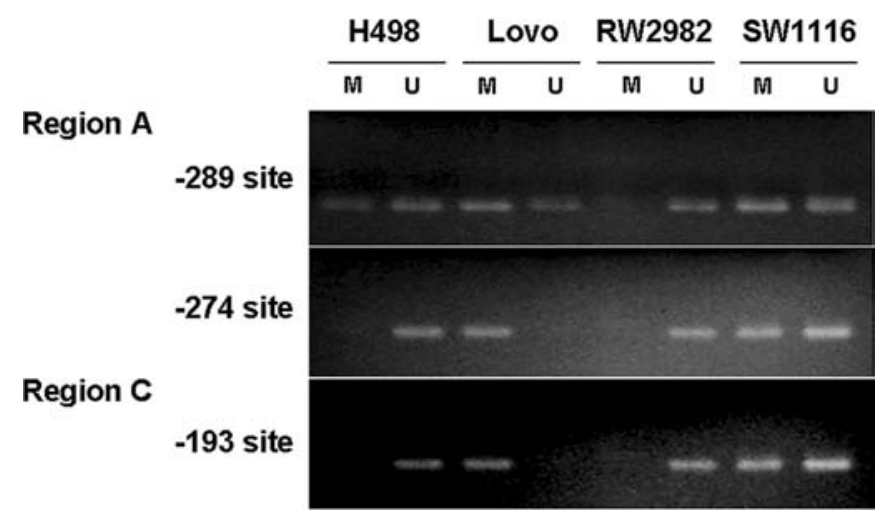

Figure 4. MUC2 methylation status at region A (-298 and -274 CpG site) and region C (-193 CpG site) in cell line study. H498 and RW2982 are unmethylated cell lines. Lovo is a highly methylated, and SW1116 is a lowmethylated cell line. we chose MSP analysis to investigate MUC2 methylation status. We performed MSP preliminary on four cell lines (H498, RW2982, Lovo and SW1116) for analyzing four sites $(-289,-274,-193$ and -160$)$ in MUC2 gene promoter. We gained similar methylation data at $-289,-274$ and -193 site (Fig. 4). As with -160 site, effective bands did not appear (data was not shown). Methylation level was low in H498 and RW2982, and high in Lovo. SW1116 is a low-methylated cell line. From these results, we tried to analyze the methylation status at $-289,-274$ and -193 site in MUC2 gene promoter of mucinous CRC and non-mucinous CRC tissues.

Methylation analysis of MUC2 gene promoter region in tissue samples. DNA methylation level of 19 mucinous CRC and 34 non-mucinous CRC was examined by using MSP analysis. Clinicopathological features of these tissues are shown in Table II. We compared the age, gender, location of 
Table III. The methylation level of MUC2 gene at 3 sites $(-289,-274$ and -193$)$ in mucinous and non-mucinous colorectal cancer tissues.

\begin{tabular}{lcccc}
\hline CpG site & $\begin{array}{c}\text { Methylation } \\
\text { status }\end{array}$ & $\begin{array}{c}\text { Mucinous CRC } \\
\mathrm{n}=19\end{array}$ & $\begin{array}{c}\text { Non-mucinous CRC } \\
\mathrm{n}=34\end{array}$ & $\mathrm{p}$-value \\
\hline-289 & + & $8(42.1 \%)$ & $30(88.2 \%)$ & 0.001 \\
-274 & - & $11(57.9 \%)$ & $4(11.8 \%)$ & 0.013 \\
& + & $5(26.3 \%)$ & $12(35.3 \%)$ & 0.001 \\
\hline
\end{tabular}

Table IV. The result of methylated CpG sites, MUC2 stainings and mucin contents in mucinous colorectal cancer tissues.

\begin{tabular}{|c|c|c|c|c|c|c|c|}
\hline \multirow[b]{2}{*}{ No. } & \multicolumn{3}{|c|}{ CpG sites } & \multirow[b]{2}{*}{$\begin{array}{c}\text { Methylation } \\
\text { status }\end{array}$} & \multirow[b]{2}{*}{$\begin{array}{l}\text { MUC2 } \\
\text { area \% }\end{array}$} & \multirow[b]{2}{*}{$\begin{array}{l}\text { MUC2 } \\
\text { IS (0-2) }\end{array}$} & \multirow[b]{2}{*}{$\begin{array}{c}\text { Mucin } \\
\%\end{array}$} \\
\hline & -289 & -274 & -193 & & & & \\
\hline 1 & $\mathrm{U}$ & $\mathrm{U}$ & $\mathbf{M}$ & 1 & 100 & 2 & 70 \\
\hline 2 & $\mathrm{U}$ & $\mathrm{U}$ & $\mathrm{U}$ & 0 & 100 & 2 & 90 \\
\hline 3 & $\mathrm{U}$ & M & $\mathrm{U}$ & 1 & 100 & 2 & 80 \\
\hline 4 & $\mathrm{U}$ & $\mathrm{U}$ & $\mathrm{U}$ & 0 & 90 & 1.7 & 50 \\
\hline 5 & $\mathbf{M}$ & $\mathrm{U}$ & $\mathrm{U}$ & 1 & 100 & 1.8 & 50 \\
\hline 6 & $\mathbf{M}$ & $\mathrm{U}$ & $\mathrm{U}$ & 1 & 100 & 2 & 50 \\
\hline 7 & $\mathbf{M}$ & $\mathrm{U}$ & $\mathrm{U}$ & 1 & 100 & 2 & 50 \\
\hline 8 & $\mathrm{U}$ & $\mathrm{U}$ & $\mathbf{M}$ & 1 & 100 & 2 & 80 \\
\hline 9 & $\mathbf{M}$ & $\mathrm{U}$ & $\mathbf{M}$ & 2 & 30 & 0.7 & 50 \\
\hline 10 & $\mathbf{M}$ & $\mathrm{U}$ & $\mathrm{U}$ & 1 & 100 & 2 & 90 \\
\hline 11 & $\mathbf{M}$ & $\mathrm{U}$ & $\mathrm{U}$ & 1 & 75 & 1.3 & 90 \\
\hline 12 & $\mathrm{U}$ & $\mathrm{U}$ & $\mathbf{M}$ & 1 & 100 & 2 & 70 \\
\hline 13 & $\mathrm{U}$ & $\mathbf{M}$ & $\mathrm{U}$ & 1 & 85 & 1.4 & 70 \\
\hline 14 & $\mathrm{U}$ & $\mathrm{U}$ & $\mathrm{U}$ & 0 & 90 & 1.7 & 90 \\
\hline 15 & $\mathrm{U}$ & $\mathrm{U}$ & $\mathrm{U}$ & 0 & 90 & 0.7 & 90 \\
\hline 16 & $\mathrm{U}$ & $\mathrm{U}$ & $\mathrm{U}$ & 0 & 90 & 1.8 & 50 \\
\hline 17 & $\mathrm{U}$ & $\mathbf{M}$ & $\mathbf{M}$ & 2 & 100 & 2 & 80 \\
\hline 18 & $\mathbf{M}$ & $\mathbf{M}$ & $\mathbf{M}$ & 3 & 50 & 1 & 90 \\
\hline 19 & $\mathbf{M}$ & $\mathbf{M}$ & $\mathbf{M}$ & 3 & 80 & 1.5 & 80 \\
\hline
\end{tabular}

IS (integrated staining intensity score $)=\mathrm{S}(1 \times \mathrm{F}+)+(2 \times \mathrm{F}++) . \mathrm{F}=$ percent $(\%) \times 10$ field. $\mathbf{M}$ highlights the positive methylation status of the $\mathrm{CpG}$ sites and $\mathrm{U}$ indicates that the $\mathrm{CpG}$ sites are not methylated.

tumor and Dukes stage. There were no statistically significant differences between these groups. However, in the Dukes stage, there was a tendency for more mucinous CRC patients in advanced stages $(57.9 \%)$ than non-mucinous CRC patients $(32.4 \%)$ which agrees with previous clinicopathological studies $(3,4)$ that mucinous CRC often presents at an advanced stage. The methylation status at 3 sites $(-289$, -274 and -193) of MUC2 gene promoter of both groups are shown in Table III. Methylation status of mucinous cancer group was lower than that of non-mucinous $\mathrm{CRC}$ in all sites (-289 site; $\mathrm{P}=0.001,-274$ site; $\mathrm{P}=0.013,-193$ site; $\mathrm{P}=0.001$ ).
In these cases, interestingly, there were exceptions that some mucinous CRC cases were highly methylated, and also, some cases were low-methylated in non-mucinous CRC group.

Histochemical study of mucin and immunohistochemical study of MUC2 expression. To compare the mucin contents (\%) between mucinous CRC and non-mucinous CRC, H\&E staining was done in both groups. As shown in Tables IV and $\mathrm{V}$, mucin contents in mucinous CRC tissues were significantly higher than those of non-mucinous CRC tissues $(\mathrm{p}<0.001)$. Next, to evaluate MUC2 protein expression in 
Table V. The result of methylated CpG sites, MUC2 stainings and mucin contents in non-mucinous colorectal cancer tissues.

\begin{tabular}{|c|c|c|c|c|c|c|c|}
\hline \multirow[b]{2}{*}{ No. } & \multicolumn{3}{|c|}{ CpG sites } & \multirow[b]{2}{*}{$\begin{array}{l}\text { Methylation } \\
\text { status }\end{array}$} & \multirow[b]{2}{*}{$\begin{array}{l}\text { MUC2b }^{\mathrm{b}} \\
\text { area } \%\end{array}$} & \multirow[b]{2}{*}{$\begin{array}{l}\text { MUC2 }{ }^{c} \\
\text { IS }(0-2)\end{array}$} & \multirow[b]{2}{*}{$\begin{array}{c}\text { Mucin }^{\mathrm{d}} \\
\%\end{array}$} \\
\hline & -289 & -274 & -193 & & & & \\
\hline 1 & $\mathbf{M}$ & $\mathbf{M}$ & $\mathbf{M}$ & 3 & 100 & 2 & 10 \\
\hline 2 & $\mathbf{M}$ & $\mathrm{U}$ & $\mathbf{M}$ & 2 & 0 & 0 & 0 \\
\hline 3 & $\mathbf{M}$ & $\mathbf{M}$ & $\mathbf{M}$ & 3 & 30 & 0.4 & 0 \\
\hline 4 & $\mathrm{U}$ & $\mathbf{M}$ & $\mathrm{U}$ & 1 & 20 & 0.3 & 5 \\
\hline 5 & $\mathbf{M}$ & $\mathbf{M}$ & $\mathbf{M}$ & 3 & 40 & 0.5 & 0 \\
\hline 6 & $\mathbf{M}$ & $\mathbf{M}$ & $\mathrm{U}$ & 2 & 0 & 0 & 0 \\
\hline 7 & $\mathbf{M}$ & $\mathrm{U}$ & $\mathrm{U}$ & 1 & 0 & 0 & 40 \\
\hline 8 & $\mathrm{U}$ & $\mathrm{U}$ & $\mathbf{M}$ & 1 & 100 & 2 & 0 \\
\hline 9 & $\mathbf{M}$ & $\mathbf{M}$ & $\mathbf{M}$ & 3 & 0 & 0 & 0 \\
\hline 10 & $\mathbf{M}$ & $\mathbf{M}$ & $\mathbf{M}$ & 3 & 100 & 1 & 5 \\
\hline 11 & $\mathrm{U}$ & $\mathbf{M}$ & $\mathbf{M}$ & 2 & 40 & 0.6 & 0 \\
\hline 12 & $\mathbf{M}$ & $\mathbf{M}$ & $\mathbf{M}$ & 3 & 100 & 1 & 5 \\
\hline 13 & $\mathbf{M}$ & $\mathrm{U}$ & $\mathbf{M}$ & 2 & 0 & 0 & 0 \\
\hline 14 & $\mathbf{M}$ & $\mathbf{M}$ & $\mathrm{U}$ & 2 & 0 & 0 & 5 \\
\hline 15 & $\mathbf{M}$ & $\mathbf{M}$ & $\mathrm{U}$ & 2 & 30 & 0.4 & 0 \\
\hline 16 & $\mathrm{U}$ & $\mathrm{U}$ & $\mathbf{M}$ & 1 & 0 & 0 & 0 \\
\hline 17 & $\mathbf{M}$ & $\mathrm{U}$ & $\mathrm{U}$ & 1 & 0 & 0 & 0 \\
\hline 18 & $\mathbf{M}$ & $\mathbf{M}$ & $\mathbf{M}$ & 3 & 0 & 0 & 0 \\
\hline 19 & $\mathbf{M}$ & $\mathbf{M}$ & $\mathbf{M}$ & 3 & 0 & 0 & 0 \\
\hline 20 & $\mathbf{M}$ & $\mathbf{M}$ & $\mathbf{M}$ & 3 & 100 & 1.7 & 0 \\
\hline 21 & $\mathbf{M}$ & $\mathbf{M}$ & $\mathbf{M}$ & 3 & 0 & 0 & 0 \\
\hline 22 & $\mathbf{M}$ & $\mathbf{M}$ & $\mathbf{M}$ & 3 & 0 & 0 & 0 \\
\hline 23 & $\mathbf{M}$ & $\mathrm{U}$ & $\mathrm{U}$ & 1 & 0 & 0 & 0 \\
\hline 24 & $\mathbf{M}$ & $\mathrm{U}$ & $\mathbf{M}$ & 2 & 0 & 0 & 0 \\
\hline 25 & $\mathbf{M}$ & $\mathrm{U}$ & $\mathbf{M}$ & 2 & 50 & 0.8 & 0 \\
\hline 26 & $\mathbf{M}$ & $\mathbf{M}$ & $\mathbf{M}$ & 3 & 80 & 1.4 & 0 \\
\hline 27 & $\mathbf{M}$ & $\mathrm{U}$ & $\mathbf{M}$ & 2 & 0 & 0 & 0 \\
\hline 28 & $\mathbf{M}$ & $\mathbf{M}$ & $\mathbf{M}$ & 3 & 0 & 0 & 0 \\
\hline 29 & $\mathbf{M}$ & $\mathbf{M}$ & $\mathbf{M}$ & 3 & 0 & 0 & 0 \\
\hline 30 & $\mathbf{M}$ & $\mathrm{U}$ & $\mathbf{M}$ & 2 & 0 & 0 & 0 \\
\hline 31 & $\mathbf{M}$ & $\mathrm{U}$ & $\mathbf{M}$ & 2 & 0 & 0 & 0 \\
\hline 32 & $\mathbf{M}$ & $\mathbf{M}$ & $\mathbf{M}$ & 3 & 100 & 2 & 20 \\
\hline 33 & $\mathbf{M}$ & $\mathbf{M}$ & $\mathbf{M}$ & 3 & 0 & 0 & 0 \\
\hline 34 & $\mathbf{M}$ & $\mathbf{M}$ & $\mathbf{M}$ & 3 & 0 & 0 & 0 \\
\hline
\end{tabular}

Compared with mucinous cancer tisses; ${ }^{\mathrm{a}} \mathrm{p}<0.01$ (Student's t-test); ${ }^{\mathrm{b}} \mathrm{p}<0.01,{ }^{\mathrm{c}} \mathrm{p}<0.01$ and ${ }^{\mathrm{d}} \mathrm{p}<0.001$ (Mann-Whitney's U test). M highlights the positive methylation status of the $\mathrm{CpG}$ sites and $\mathrm{U}$ indicates that the $\mathrm{CpG}$ sites are not methylated.

those CRC tissues, we performed immunohistochemistry by using anti-MUC2 antibody, CCP58. In normal colon tissues, intense MUC2 staining was observed in the perinuclear cytoplasm of goblet cells (Fig. 5a) because CCP58 recognizes an epitope in the MUC2 tandem repeat peptide region that becomes masked when full glycosylation occur. Therefore, MUC2 mucin core proteins that are newly synthesized and not yet glycosylated are stained in perinuclear regions. However, fully-glycosylated MUC2 mucins in the vacole are not stained. On the contrary, staining patterns of cancer cells were different from normal tissue (Fig. 5b-f). In mucinous cancer tissues, strong and diffuse cytoplasmic staining of cancerous epithelial cells is seen (Fig. 5b). Also, there were many floating cells in mucin lakes (Fig. 5c). Seventeen of 19 mucinous cancer tissues were well-stained and two cases (no. 9 and 18) were focally stained. In non-mucinous cancer tissues, 21 of 34 samples $(61.8 \%)$ were negative for staining (Fig. 5d). Six of 34 samples (17.6\%) were focally stained (Fig. 5e). This staining pattern predicts the heterogeneity of cancer cells. Seven samples (20.6\%) were diffusely stained like mucinous cancer tissues (Fig. 5f). MUC2-staining area (\%) and integrated 


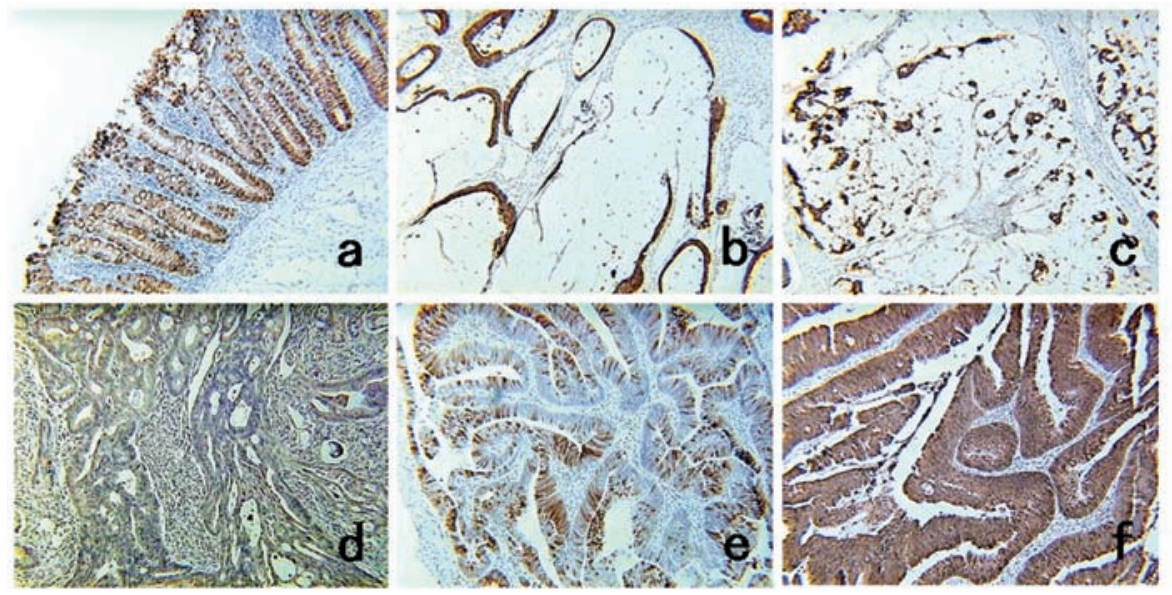

Figure 5. Immunohistochemical staining of CRC tissues with MUC2 antibody (CCP58). (a) Staining of normal tissue. Perinuclear cytoplasm staining was predominantly seen in goblet cells (x100). (b and c) Staining of mucinous CRC tissues (x100). (b) Strong and diffuse cytoplasmic staining of cancerous epithelial cells is seen. (c) There were many floating cancer cells in mucin lakes. (d-f) Staining of non-mucinous CRC tissues (x 100). (d) Negative staining $(n=21)$. (e) Focal staining $(n=6)$. This pattern indicates the heterogeneity of cancer cells. (f) Well-stained pattern like mucinous cancer tissue $(n=7)$.

A

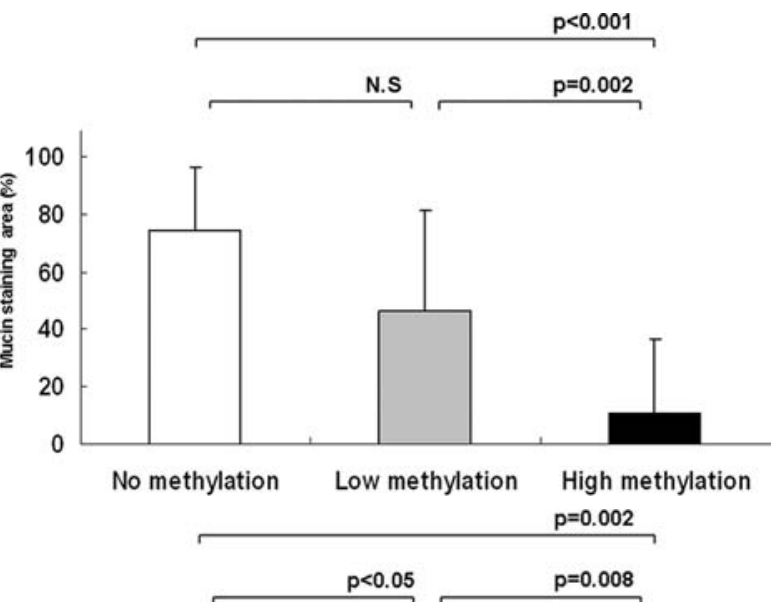

B
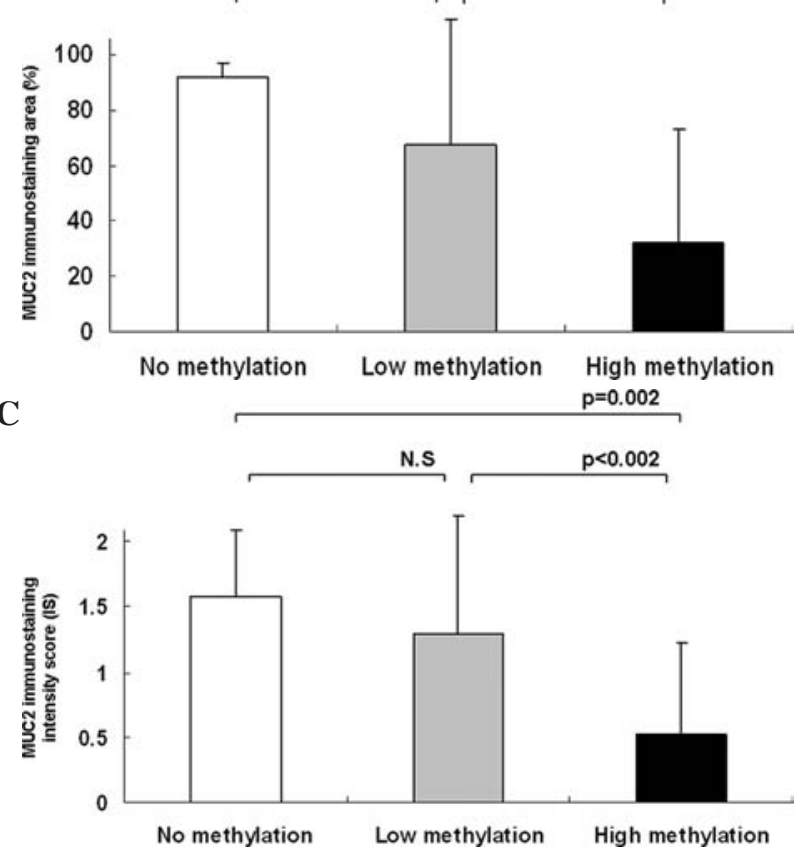

Figure 6. Correlation of methylation degree and its effect on (A) mucin area (\%), (B) MUC2-staining area (\%) and (C) MUC2-staining intensity score. $\mathrm{CRC}$ cases were categorized in the low-methylation group if one $\mathrm{CpG}$ site was methylated. If plural $\mathrm{CpG}$ sites were methylated, the case was categorized in the high-methylation group. staining intensity score (IS) are shown in Tables IV and V. Both staining evaluations indicated that mucinous CRC group significantly expressed MUC2 rather than non-mucinous CRC group $(\mathrm{P}<0.01)$. Regarding the mucinous $\mathrm{CRC}$ group, most staining areas and scores were remarkably high except for 2 cases. In these well-stained cases, we compared the MUC2 gene promoter methylation status with these staining patterns, with the result that 15 cases were low-methylated. We considered methylation status as low level if the methylation was detected at only one $\mathrm{CpG}$ site. When several $\mathrm{CpG}$ sites were methylated, we categorized the case in highmethylated group. Also, we considered a case as well-stained when the staining area (\%) was $>60 \%$ or staining intensity (IS) was $>1.2$. Two cases (no. 17 and 19) were well stained whereas these were highly methylated. Further two cases (no. 9 and 18), which were focally stained, were highly methylated. Therefore, except for these 2 cases (no. 17 and 19), 17 cases agreed with our cell line study. On the other hand, there were various aspects in non-mucinous CRC group. In 17 cases, MUC2 was not detected followed by high methylation status of MUC2. Case 8 was low-methylated with MUC2 high-expressing case. Thus, these 18 cases were completely theoretical. In 5 samples (no. 3, 5, 11, 15 and 25), focal staining remained, whereas methylation status was high. As with other 5 samples (no. 4, 7, 16, 17 and 23), only one CpG site was methylated (low-methylated) followed by MUC2 faint or negative staining. Thus, the degree of methylation of MUC2 played a regulatory effect on its expression. There were 6 exceptions those were highly methylated with strong MUC2 expression (no. 1, 10, 12, 20, 26 and 32).

We compared these data between mucinous and nonmucinous group. Next step, we analyzed these results from the view point of the degree of methylation status with its suppressive effects (Fig. 6A, B and C). As shown in these figures, we assigned all $53 \mathrm{CRC}$ samples into the nomethylation group, the low-methylation group $(n=1)$ or the high-methylation group $(\mathrm{n}=2,3)$, and compared MUC2 expression levels and mucin contents (\%) among them. There were statistical differences between the no-methylation group and the high-methylated group; $\mathrm{p}<0.001$ in mucin area (\%); 
$\mathrm{p}=0.002$ in MUC2-staining area $(\%) ; \mathrm{p}=0.002$ in MUC2staining intensity score. There were also significant differences between the low-methylation group and the highmethylation group; $\mathrm{p}=0.002$ in mucin area $(\%) ; \mathrm{p}=0.008$ in MUC2-staining area (\%); $<<0.002$ in MUC2-staining intensity score. As with between the no-methylation group and the low-methylation group, there was a statistical difference only in MUC2-staining area $(\%)(\mathrm{p}<0.05)$. These results indicated that MUC2 expression and mucin contents decreased in accordance with the increase of methylation status.

\section{Discussion}

The correlation of the methylation of MUC2 gene promoter with its expression has been examined in cell lines by many researchers indicating that methylation of the gene promoter suppresses MUC2 expression (24,26,28-34,37). We tried to prove this theory by using human mucinous CRC and nonmucinous CRC tissues and showed that methylation status of mucinous CRC, which expressed MUC2 well, was low, whereas that of non-mucinous CRC was at high level. Furthermore, we showed that MUC2 expression level was affected by its methylation status. Thus, our results were almost similar with the cell line reports. Human cancer tissue samples are difficult to use for experiments because they contain several epithelial and stromal cell types. To get reliable results, careful microdissection procedure is required. Therefore, our results, in some cases were not as expected, possibly due to the contamination of these cells. Generally, DNA from tissue samples was not sufficient enough for PCR thus pre-amplification was an ideal method to raise the reliability of the experiment. Therefore, we tried the pre-amplification after appropriate areas in MUC2 gene promoter was detected by sodium bisulfite sequencing method. This sequencing method is also an effective way to analyze the methylation status of $\mathrm{CpG}$ sites by using sample RNA (38). In this sequencing analysis for cell lines, we examined $21 \mathrm{CpG}$ sites of MUC2 gene in 13 MUC2-nonexpressing CRC cell lines and four MUC2-expressing CRC cell lines. In all MUC2-non-expressing cell lines, there was near accordance that the methylation status at 4 sites $(-289$, $-274,-193$ and -160) were at high level. In other sites, methylation status was cell-dependent (Figs. 1A and 2). On the other hand, in four MUC2-expressing cell lines, methylation status was at low level in MUC2 promoter region (Figs. 1B and 2). From the comparison of these results, we hypothesized that these $4 \mathrm{CpG}$ sites may play an important role for MUC2 expression. Before starting the analysis in tissue samples, we tried to confirm these 4 sites in a CRC cell line study with the result that methylation status in 3 sites was proved in the 4 cell lines. One CpG site, at -160 , is also expected to be important in the regulation of MUC2 and we tried to show the methylation status by several MSP conditions, however, we could not get a sufficient result. Sequencing pattern around the target area or quality of primer set may be the reasons of the failure. Thus, this $\mathrm{CpG}$ site remains to be further examined.

MSP analysis at these sites on tissues accorded with the cell line study. As predicted, methylation status of mucinous
CRC group was significantly lower than that of nonmucinous CRC group. On the contrary, MUC2 expressions in mucinous CRC group were more predominant than those in non-mucinous CRC group, proven by immunohistochemistry (Tables IV and V). These data predicted the close correlation between methylation status and its suppressive effect on MUC2 expression. Therefore, we evaluated all the samples from the view point of methylation degree of MUC2 promoter region. As shown in Fig. 6A, B and C, there were same tendencies that MUC2 expression and mucin contents decreased in accordance with the increase of methylation status. Thus, we could show that MUC2 expression level depends on its methylation status in the tissue study.

Next, we inspected each sample individually. Fifteen cases of mucinous CRC group and 18 cases of non-mucinous $\mathrm{CRC}$ group were as had been expected. As with the rest of mucinous CRC samples, 4 cases (no. 9, 17, 18 and 19) were highly-methylated, but no. 9 and 18 showed decrease of MUC2 expression. Therefore, we considered no. 17 and 19 as exceptions. On the contrary, in non-mucinous CRC group, the rest of the cases were without complications. Five samples in non-mucinous CRC group were low methylated (only one $\mathrm{CpG}$ site was methylated), but their MUC2 expressions were strongly suppressed, indicating that even though the methylation level is low, it may be enough to regulate MUC2 expression. Other 5 samples were highly methylated but focal staining remained. Thus, these 10 cases were slightly obscure, but they showed more or less regulatory effects on MUC2 expression due to the methylation. The degree of suppressive effect of methylation depended on each case type. Here, we need to consider the mucin-producing components in non-mucinous cancer tissues as shown in Table $\mathrm{V}$ because contamination of these parts may lower specificity of MSP and immunohistochemistry. These results may be part due to the heterogeneousity of cancer cells.

As shown above, there were some exceptions. In mucinous CRC group, 2 samples were unexpectedly highly methylated whereas they maintained MUC2 expression. On the other hand, 6 samples in non-mucinous CRC were highly methylated followed by unexpected strong MUC2 expression. Thus, our data suggested other factors that also affect MUC2 expression directly or indirectly. There are many reports on the MUC2 regulation by inflammatory cytokines (TNF- $\alpha$, interleukins-1, -4, -6, -9, -13) (12-17), growth factors (epidermal growth factor, transforming growth factors $\alpha$ and $\beta)(18-21)$, and transcription factors [Sp1 (24), NF-кB (11), HATH1 (27), Cdx-2 (26), and p53 (25)]. Generally, in CRC tissues (mucinous and non-mucinous $\mathrm{CRC}$ ), there are many inflammatory cytokines and growth factors so that these factors may affect the MUC2 expression. HATH1, a basic helix-loop-helix transcription factor that is the human homologues of Drosophila atonal, can be one of the responsible factors because HATH1 expression is important for up-regulation of MUC2 in mucinous CRC. A previous study showed that forced HATH1 expression in colon cancer cells results in increased MUC2 expression (39). We also comfirmed that there were few cases expressing HATH1 in non-mucinous CRC tissues (7\%), although all mucinous CRC were expressed (27). As with 
two cases in our mucinous CRC group, HATH1 may make up for the decrease of MUC2 expression due to high methylation.

Cdx2, a member of the caudal-related homeobox gene family, as judged from their sequence homology to the caudal gene of Drosophila melanogaster $(40,41)$, is also an important transcription factor for MUC2 expression. Yamamoto et al showed that Cdx2 interacts with the MUC2 promoter and activates MUC2 transcription (26). Mesquita et al showed that Cdx2 activated the expression of MUC2 and also identified Cdx2-binding sites on MUC2 gene at -177/171 and -191/-187 (42). Kawai et al reported that Cdx2 gene was methylated in nearly $40 \%$ of CRC cases and suggested this methylation may play a key role in inactivating $\mathrm{Cdx} 2$ expres-sion (43). Therefore, methylation of $\mathrm{Cdx} 2$ gene may affect the results of MUC2 expression. In addition, these Cdx2-binding sites are very close to $\mathrm{C}$ area. This fact indicates the possibility that Cdx2-binding sites were affected by MUC2 gene methylation followed by the suppression of Cdx2-binding ability. Hence, methylation status of Cdx2 and Cdx2-binding ability also remains to be examined.

In summary, we confirmed that the methylation status of MUC2 gene promoter in mucinous CRC tissue was significantly lower than that in non-mucinous CRC tissue. We also showed that MUC2 gene methylation predominantly regulates its expression not only in a cell line study, but also in a tissue study. Finally, the existence of exceptions predicts the possibility of the participation of other factors in MUC2 expression in CRC tissue.

\section{Acknowledgements}

This work was supported in part by the Department of Veterans Affairs Medical Research Service, Oberkotter Foundation grant and Theodora Betz Foundation grant.

\section{References}

1. Secco GB, Fardelli R, Campora E, Lapertosa G, Gentile R, Zoli S and Prior C: Primary mucinous adenocarcinomas and signetring cell carcinomas of colon and rectum. Oncology 51: 30-34, 1994.

2. Green JB, Timmcke AE, Mitchell WT, Hicks TC, Gathright JB Jr and Ray JE: Mucinous carcinoma-just another colon cancer? Dis Colon Rectum 36: 49-54, 1993.

3. Zhang H, Evertsson S and Sun X: Clinicopathological and genetic characteristics of mucinous carcinomas in the colorectum. Int J Oncol 14: 1057-1061, 1999.

4. Nozoe T, Anai H, Nasu S and Sugimachi K: Clinicopathological characteristics of mucinous carcinoma of the colon and rectum. J Surg Oncol 75: 103-107, 2000.

5. Song GA, Deng G, Bell I, Kakar S, Sleisenger MH and Kim YS: Mucinous carcinomas of the colorectum have distinct molecular genetic characteristics. Int J Oncol 26: 745-750, 2005.

6. Kakar S, Aksoy S, Burgart LJ and Smyrk TC: Mucinous carcinoma of the colon: correlation of loss of mismatch repair enzymes with clinicopathologic features and survival. Mod Pathol 17: 696-700, 2004.

7. Hawkins N, Norrie M, Cheong K, Mokany E, Ku SL, Meagher A, $\mathrm{O}^{\prime}$ Connor $\mathrm{T}$ and Ward $\mathrm{R}$ : $\mathrm{CpG}$ island methylation in sporadic colorectal cancers and its relationship to microsatellite instability. Gastroenterology 122: 1376-1387, 2002.

8. Nagasaka T, Sasamoto H, Notohara K, Cullings HM, Takeda M, Kimura K, Kambara T, MacPhee DG, Young J, Leggett BA, Jass JR, Tanaka N and Matsubara N: Colorectal cancer with mutation in BRAF, KRAS, and wild-type with respect to both oncogenes showing different patterns of DNA methylation. J Clin Oncol 22: 4584-4594, 2004.
9. Tanaka H, Deng G, Matsuzaki K, Kakar S, Kim GE, Miura S, Sleisenger $\mathrm{MH}$ and Kim YS: BRAF mutation, $\mathrm{CpG}$ island methylator phenotype and microsatellite instability occur more frequently and concordantly in mucinous than non-mucinous colorectal cancer. Int J Cancer 118: 2765-2771, 2006.

10. Hanski C: Is mucinous carcinoma of the colorectum a distinct genetic entity? Br J Cancer 72: 1350-1356, 1995.

11. Li JD, Feng W, Gallup M, Kim JH, Gum J, Kim Y and Basbaum C: Activation of NF-kappaB via a Src-dependent RasMAPK-pp90rsk pathway is required for Pseudomonas aeruginosa-induced mucin overproduction in epithelial cells. Proc Natl Acad Sci USA 95: 5718-5723, 1998.

12. Enss ML, Cornberg M, Wagner S, Gebert A, Henrichs M, Eisenblatter R, Beil W, Kownatzki R and Hedrich HJ: Proinflammatory cytokines trigger MUC gene expression and mucin release in the intestinal cancer cell line LS180. Inflamm Res 49: 162-169, 2000.

13. Fischer BM, Rochelle LG, Voynow JA, Akley NJ and Adler KB: Tumor necrosis factor-alpha stimulates mucin secretion and cyclic GMP production by guinea pig tracheal epithelial cells in vitro. Am J Respir Cell Mol Biol 20: 413-422, 1999.

14. Dabbagh K, Takeyama K, Lee HM, Ueki IF, Lausier JA and Nadel JA: IL-4 induces mucin gene expression and goblet cell metaplasia in vitro and in vivo. J Immunol 162: 6233-6237, 1999.

15. Levine SJ, Larivee P, Logun C, Angus CW, Ognibene FP and Shelhamer JH: Tumor necrosis factor-alpha induces mucin hypersecretion and MUC-2 gene expression by human airway epithelial cells. Am J Respir Cell Mol Biol 12: 196-204, 1995.

16. Shim JJ, Dabbagh K, Ueki IF, Dao-Pick T, Burgel PR, Takeyama K, Tam DC and Nadel JA: IL-13 induces mucin production by stimulating epidermal growth factor receptors and by activating neutrophils. Am J Physiol Lung Cell Mol Physiol 280: L134-L140, 2001.

17. Yoon JH, Kim KS, Kim HU, Linton JA and Lee JG: Effects of TNF-alpha and IL-1 beta on mucin, lysozyme, IL-6 and IL-8 in passage-2 normal human nasal epithelial cells. Acta Otolaryngol 119: 905-910, 1999.

18. Nadel JA: Role of epidermal growth factor receptor activation in regulating mucin synthesis. Respir Res 2: 85-89, 2001.

19. Perrais M, Pigny P, Copin MC, Aubert JP and Van Seuningen I: Induction of MUC2 and MUC5AC mucins by factors of the epidermal growth factor (EGF) family is mediated by EGF receptor/Ras/Raf/extracellular signal-regulated kinase cascade and Sp1. J Biol Chem 277: 32258-32267, 2002.

20. Takeyama K, Dabbagh K, Lee HM, Agusti C, Lausier JA, Ueki IF, Grattan KM and Nadel JA: Epidermal growth factor system regulates mucin production in airways. Proc Natl Acad Sci USA 96: 3081-3086, 1999.

21. Jono H, Shuto T, Xu H, Kai H, Lim DJ, Gum JR Jr, Kim YS, Yamaoka S, Feng XH and Li JD: Transforming growth factor-beta -Smad signaling pathway cooperates with NFkappa B to mediate nontypeable Haemophilus influenzaeinduced MUC2 mucin transcription. J Biol Chem 277: 4554745557, 2002.

22. Lee HW, Ahn DH, Crawley SC, Li JD, Gum JR Jr, Basbaum CB, Fan NQ, Szymkowski DE, Han SY, Lee BH, Sleisenger MH and Kim YS: Phorbol 12-myristate 13-acetate up-regulates the transcription of MUC2 intestinal mucin via Ras, ERK, and NF-kappa B. J Biol Chem 277: 32624-32631, 2002.

23. Koo JS, Yoon JH, Gray T, Norford D, Jetten AM and Nettesheim P: Restoration of the mucous phenotype by retinoic acid in retinoid-deficient human bronchial cell cultures: changes in mucin gene expression. Am J Respir Cell Mol Biol 20: 43-52, 1999.

24. Gum JR, Hicks JW and Kim YS: Identification and characterization of the MUC2 (human intestinal mucin) gene 5'flanking region: promoter activity in cultured cells. Biochem J 325: 259-267, 1997.

25. Ookawa K, Kudo T, Aizawa S, Saito H and Tsuchida S: Transcriptional activation of the MUC2 gene by p53. J Biol Chem 277: 48270-48275, 2002.

26. Yamamoto H, Bai YQ and Yuasa Y: Homeodomain protein CDX2 regulates goblet-specific MUC2 gene expression. Biochem Biophys Res Commun 300: 813-818, 2003.

27. Park ET, Oh HK, Gum JR Jr, Crawley SC, Kakar S, Engel J, Leow CC, Gao WQ and Kim YS: HATH1 expression in mucinous cancers of the colorectum and related lesions. Clin Cancer Res 12: 5403-5410, 2006. 
28. Siedow A, Szyf M, Gratchev A, Kobalz U, Hanski ML, BumkeVogt C, Foss HD, Riecken EO and Hanski C: De novo expression of the Muc2 gene in pancreas carcinoma cells is triggered by promoter demethylation. Tumour Biol 23: 54-60, 2002.

29. Ho JJ, Han SW, Pan PL, Deng G, Kuan SF and Kim YS: Methylation status of promoters and expression of MUC2 and MUC5AC mucins in pancreatic cancer cells. Int J Oncol 22: 273-279, 2003

30. Hanski C, Riede E, Gratchev A, Foss HD, Bohm C, Klussmann E, Hummel M, Mann B, Buhr HJ, Stein H, Kim YS, Gum J and Riecken EO: MUC2 gene suppression in human colorectal carcinomas and their metastases: in vitro evidence of the modulatory role of DNA methylation. Lab Invest 77: 685-695, 1997.

31. Riede E, Gratchev A, Foss HD, Mann B, Buhr HJ and Hanski C: Increased methylation of promotor region suppresses expression of MUC2 gene in colon carcinoma cells. Langenbecks Arch Chir (Suppl Kongressbd) 115: 299-302, 1998.

32. Gratchev A, Siedow A, Bumke-Vogt C, Hummel M, Foss HD, Hanski ML, Kobalz U, Mann B, Lammert H, Mansmann U, Stein H, Riecken EO and Hanski C: Regulation of the intestinal mucin MUC2 gene expression in vivo: evidence for the role of promoter methylation. Cancer Lett 168: 71-80, 2001.

33. Hamada T, Goto M, Tsutsumida H, Nomoto M, Higashi M, Sugai T, Nakamura S and Yonezawa S: Mapping of the methylation pattern of the MUC2 promoter in pancreatic cancer cell lines, using bisulfite genomic sequencing. Cancer Lett 227: $175-184,2005$

34. Yamada N, Hamada T, Goto M, Tsutsumida H, Higashi M, Nomoto $\mathrm{M}$ and Yonezawa S: MUC2 expression is regulated by histone H3 modification and DNA methylation in pancreatic cancer. Int J Cancer 119: 1850-1857, 2006.

35. Schoeppner HL, Raz A, Ho SB and Bresalier RS: Expression of an endogenous galactose-binding lectin correlates with neoplastic progression in the colon. Cancer 75: 2818-2826, 1995.
36. Ho SB, Ewing SL, Montgomery CK and Kim YS: Altered mucin core peptide immunoreactivity in the colon polypcarcinoma sequence. Oncol Res 8: 53-61, 1996.

37. Mesquita P, Peixoto AJ, Seruca R, Hanski C, Almeida R, Silva F, Reis C and David L: Role of site-specific promoter hypomethylation in aberrant MUC2 mucin expression in mucinous gastric carcinomas. Cancer Lett 189: 129-136, 2003.

38. Deng G, Chen A, Hong J, Chae HS and Kim YS: Methylation of $\mathrm{CpG}$ in a small region of the hMLH1 promoter invariably correlates with the absence of gene expression. Cancer Res 59: 2029-2033, 1999.

39. Leow CC, Romero MS, Ross S, Polakis P and Gao WQ: Hath1, down-regulated in colon adenocarcinomas, inhibits proliferation and tumorigenesis of colon cancer cells. Cancer Res 64: 6050-6057, 2004.

40. Yonezawa S, Nakamura A, Horinouchi M and Sato E: The expression of several types of mucin is related to the biological behavior of pancreatic neoplasms. J Hepatobiliary Pancreat Surg 9: 328-341, 2002.

41. Adsay NV, Merati K, Andea A, Sarkar F, Hruban RH, Wilentz RE, Goggins M, Iocobuzio-Donahue C, Longnecker DS and Klimstra DS: The dichotomy in the preinvasive neoplasia to invasive carcinoma sequence in the pancreas: differential expression of MUC1 and MUC2 supports the existence of two separate pathways of carcinogenesis. Mod Pathol 15: 10871095, 2002.

42. Mesquita P, Jonckheere N, Almeida R, Ducourouble MP, Serpa J, Silva E, Pigny P, Silva FS, Reis C, Silberg D, Van Seuningen I and David L: Human MUC2 mucin gene is transcriptionally regulated by $\mathrm{Cdx}$ homeodomain proteins in gastrointestinal carcinoma cell lines. J Biol Chem 278: 51549-51556, 2003.

43. Kawai H, Tomii K, Toyooka S, Yano M, Murakami M, Tsukuda K and Shimizu N: Promoter methylation downregulates CDX2 expression in colorectal carcinomas. Oncol Rep 13: 547-551, 2005. 